PhD Thesis

\title{
Screening and characterization of plant physiological traits using photosynthetic and phenotyping tools
}

Submitted by

Kenny Paul

Institute of Plant Biology, Biological Research Centre- HAS

Supervisor: Prof. Imre Vass, Director of Plant Biology Institute, BRC-HAS

In partial fulfillment of the requirements

For the Degree of Doctor of Philosophy

Faculty of Science and Informatics, University of Szeged,

Szeged, Hungary 


\section{Introduction}

Plants have to deal with various complex types of interactions involving numerous environmental factors such as temperature, light intensity, water availability and soil composition. When the environmental factors extend beyond an optimal range which is characteristic for a particular species, the plant will be subjected to a varying level of stress. There are stress sensitive and resistant plants based on the effectiveness of the protective responses caused by stress. The resistance of the plant to withstand various stress factors plays a vital role for its growth and development. The most important concept of agricultural plant breedings is to gradually form stress resistant crops from stress sensitive cultivars. So breeding of plants for tolerance to various environmental stresses drought, salinity, temperature and desiccation needs proper understanding of physiological characteristics and natural variations.

Growth and yield are functions of a large number of metabolic processes, which are affected by environmental and genetic factors. Studies of growth pattern and its understanding not only tell us how plant accumulates dry matter, but also reveals the events which can make a plant more or less productive. The need to bridge the gap between genotype and phenotype, correlate gene function, discover plant performance, mechanisms and adaptations of plant responses to the environment could be solved by using fast and high resolution plant phenotyping tools. Mining natural variations of plant physiological growth and correlate aspects of 'agronomical and morphological' traits provides a powerful tool for optimising crop productivity. Our approach was based on the prediction and characterisation of photosythetic and phenotyping parameters which correlate with physiological trait characteristics. We 
studied important plant physiological traits in drought, salinity, desiccation and biomass production models along with natural variations.

\section{Main objectives of the thesis}

Our research group has been working for years in the development of a complex stress diagnostic system which could be used for studying and characterising plant growth and development under various stressfull conditions. Our primary interest here was to correlate natural variations of physiological responses using photosynthetic and phenotyping tools. By considering these main objectives, our aims were:

1) To characterise key physiological and economically important traits 'biomass and grain yield'using our complex stress diagnostic protocols.

2) To compare the yields of biomass and grain production based on the phenotypic and photosynthetic parameters obtained during biomass accumulation and grain filling period.

3) To evaluate prediction of biomass and grain yield based on the photosynthetic measurements taken from 'secondary leaves' of vegetative phase and 'flag leaf' of grain filling reproductive phase in sensitive and tolerant wheat varieties under severe drought and salinity stress conditions.

4) To monitor the synergistic effects of drought and salt stress in various wheat cultivars of different geographic origin. To explain the effects of high salt stress on energy absorption and energy dissipation on the basis of various parameters from fluorescence induction curves.

5) To deduce electron flow responses under desiccation and rehydration of the resurrection plant Haberlea rhodopensis grown in different natural ecotypes. 
6) To determine the photosynthetic efficacy of tetraploid willow plants for enhanced growth and biomass production.

\section{Methods}

To address the above questions we chose methods that could connect morphological, physiological and photosynthetic characteristics in plants. Mechanisms and efficiency associated with photosystem II, photosystem I, stomatal and $\mathrm{CO}_{2}$ diffusion, light absorbance efficiency were correlated with physiological trait parameters.

Specific methods used were:

$>$ Fast fluorescence and $\mathrm{P} 700$ redox kinetics

$>$ Gas exchange measurements of $\mathrm{CO}_{2}$ fixation rates

Light curves of electron transport responses in photosytem I and II

Thermal imaging

Digital imaging

Pigment, proline and relative water content determinations

\section{Summary of findings}

Our primary interest in the present work was to correlate natural variations of physiological responses using photosynthetic and plant phenotyping tools. Our correlations and characterisation can be useful for the breeders who could select the varieties according to the stress resistance related beneficial properties plants. The results obtained by the application of our low cost stress diagnostic system will also be useful for taking precautionary measures against various stresses before visual symptoms appear. 


\section{$>$ Characterization of biomass and grain yield under severe drought}

Non-invasive photosynthetic measurements provide highly useful tools for making reliable predictions of physiological traits of wheat and other plants. Our findings demonstrate that the agronomically highly important traits of biomass and grain yield are not necessarily correlated in wheat and possibly in other cereal crops. Therefore, phenotyping of biomass responses alone is not sufficient for predictions of grain yield changes. As a consequence, phenotyping protocols should include grain yield assessment when the aim is the optimization of grain yield and grain yield stability under stress conditions.

Our results support the importance of cyclic electron flow in drought stress tolerance. We can also conclude that changes in physiological parameters show different responses to drought stress depending on the developmental stage of leaves in the case of the studied two cultivars. Flag leaves, which serve as grain supporting leaves show similar response in their $\mathrm{CO}_{2}$ fixation, drought factor index, and electron transport parameters as the grain yield, whereas the secondary leaves, which support overall green biomass growth show similar responses as biomass accumulation. These findings are warranted by the presented results for the Cappelle Desprez and Plainsman V cultivars.

\section{Characterization of biomass and grain yield traits under salinity and drought}

The responses of wheat to different stress conditions have been analysed and revealed differences in the effects of salt and drought stress in various wheat cultivars from different geographical regions (Azerbaijan, Serbia and Austria). 
The rate on net photosynthesis, measured by $\mathrm{CO}_{2}$ gas exchange, was also affected most significantly by the combination of salt stress and water limitation. Accumulation of the osmoprotectant proline, was affected only to a small extent by water limitation and salt stress when applied separately, but proline was induced significantly by the combined application of the two stress factors. At the same time, biomass and grain yield were significantly reduced in drought as well as drought plus salt stress combination due to stomatal closure in the source region and decreased carbon partitioning from the sink region, respectively. But the minor effect of salt stress under well watered condition shows that agricultural crop loss due to salinity could be prevented by providing normal irrigation.

\section{Electron transport responses in desiccating Haberlea ecotypes}

Compared to the widely investigated, more common shade acclimated one, the high irradiance acclimated ecotype of Haberlea rhodopensis performs more effective protective mechanism in its photosynthesis. Under drought stress, the CEF is enhanced together with constant thermal energy dissipation of the PSII, whereas under severe desiccation, the PSII complex becomes inactive and acceptor-side limitation factors start to inhibit the PSI function. Under rehydration, the photosynthetic function recovers rapidly together with an increase in the CEF that may contribute to the energy-dependent recovery processes in the metabolism. In contrast, the shade ecotype showed these protective mechanisms only under severe desiccation and upon rewatering, all the recovery processes proved to be slower resulting in a significantly delayed restoration of the photosynthetic functions. Therefore, growing conditions and acclimation processes on the natural habitat 
strongly influence the desiccation tolerance of this homoiochlorophyllous resurrection plant species.

\section{Photosynthetic efficiency of willows developed by genome duplication}

Higher net $\mathrm{CO}_{2}$ uptake rate and increased transpiration through leaves of tetraploid willows plays a significant role in enhanced growth and biomass production for the energy willow Salix viminalis L. Light response curves of PSI and PSII revealed higher electron trnasport rates in the tetraploid leaves analyzed from plants grown under both field and greenhouse conditions. Chlorophyll and carotenoid levels were observed to be significantly higher in tetraploid willow genotypes grown in field conditions, which substantiate the functional characteristics for photosynthetic efficacy.

\section{ÖSSZEFOGLALÁS}

Munkánk célja a növényi biomassza-növekedés jellemzése volt fotoszintetikus mérések és komplex fenotipizálási megközelítés alkalmazásával. Az általunk felderített összefüggések és stresszindikátorok fontos alkalmazást nyerhetnek fokozott stressztoleranciával rendelkező növényi vonalak kiválasztásában.

\section{A biomassza és terméshozam jellemzése búzanövényekben szárazságstressz alatt}

A nem invazív fotoszintézis mérési módszerek hatékony eszközt biztosítanak a búza és egyéb növények fiziológiai sajátságainak jellemzésére. A Cappelle Desprez és Plainsman V modell búzafajtákon végzett vizsgálataink eredményei azt mutatják, hogy olyan mezőgazdaságilag is fontos tulajdonságok, mint a biomassza és 
terméshozam nem feltétlenül függenek össze a búzában és egyéb gabonanövényekben. Ezért a biomassza-válaszok fenotipizálása önmagában nem elegendő a terméshozamban bekövetező változások előrejelzésére. Ennek következtében a fenotipizálási protokolloknak tartalmazniuk kell a terméshozamfelmérést is, ha a cél a hozam optimalizálása és stabilitás biztosítása stresszkörülmények között.

Az eredmények megerösítik a ciklikus elektrontranszport-folyamatok jelentőségét a szárazságtürésben. Azt is megállapíthatjuk, hogy az élettani paraméterek változásai különböző válaszokat mutatnak a levelek fejlettségi állapotától függően. A magfejlődést közvetlenül meghatározó zászlóslevelek élettani jellemzőinek (széndioxid-fixáció, szárazságfaktor index, elektrontranszport paraméterek) változásai összefüggést mutatnak a terméshozammal. Ugyanakkor a másodlagos levelek jellemzői hasonló összefüggéseket mutatnak a zöld biomassza felhalmozódásának tekintetében.

$>$ A biomassza és terméshozam tulajdonságainak jellemzése búzanövényekben só- és szárazságstressz alatt

A növényi stresszválaszok komplex jelemzésére kifejlesztett módszer feltárta a búzanövényekben só- és szárazságstressz által okozott hatásokban mutatkozó eltéréseket a különböző földrajzi területekröl (Azerbajdzsán, Szerbia és Ausztria) származó fajták esetén. A nettó fotoszintézis mértéke, a Co2 gázcserét vizsgálva, szintén érzékenynek mutatkozott a só- és szárazságstressz kombinációjára. A prolin, ozmotikus védő fehérje, felhalmozódását a külön külön alkalmazott só- és szárazságstressz nem befolyásolta számottevően, ellenben amikor a két stresszfaktor egyszerre volt jelen a prolin termelődés jelentősen nőtt. A biomassza-produkció és a terméshozam jelentős csökkenést mutatott szárazság esetén és kombinált só- és 
szárazság stressz körülményei között, aminek oka a sztómazáródás miatt csökkent mértékű $\mathrm{CO}_{2}$-fixálás, illetve a csökkent mennyiségü szervesanyag-allokáció a magok irányába. A megfelelő talajnedvesség mellett elhanyagolható hatást okozó sóstressz arra utal, hogy megfelelő öntözéssel megelőzhető a talaj magas sótartalma miatt bekövetkező termésveszteség.

Elektrontranszport válaszok alacsony és magas fényintenzitásokhoz adaptálódott Haberlea ökotípusokban

A Haberlea rhodopensis növények rendelkeznek azzal a kölönleges tulajdonsággal, hogy víztartalmuk 95 \%-ának elvesztése után is képesek fotoszintetikus és fiziológiai aktivitásuk visszaállítására. Eredményeink szerint a gyakrabban vizsgált és elterjedtebb árnyékos fényviszonyokhoz adaptálódott Haberlea rhodopensis ökotípussal szemben a magasabb fényintenzitásokhoz akklimatizálódott Haberlea ökotípus sokkal hatékonyabb fotoszintézis védelmi mechanizmusokkal rendelkezik. Szárazságstressz hatására a lineáris elektrontranszport folyamatok fokozatosan gátlódnak, ezzel párhuzamosan a fotoprotektív ciklikus elektron transzport (CEF) hatékonysága megnövekszik. Rehidratáció alatt a fényadaptált ökotípus esetén a fotoszintetikus funkciók gyorsan visszaállnak hidratált levelekre jellemző értékekre. Ezzel ellentétben az árnyékadaptált ökotípus esetén a regenerációs lépesek lassabbnak bizonyultak, ami a fotoszintetikus funkciók késleltetett visszaállítását jelentette.

\section{Tetraploid energiafüz fotoszintetikus hatékonyságának jellemzése}

A tetraploid füzvonalak magasabb nettó $\mathrm{CO}_{2}$-felvételéről és levél gázcsereértékeiröl kimutattuk, hogy jelentős szerepet játszanak a fás szárú Salix Viminalis 
gyorsabb növekedésében és hatékonyabb biomassza-termelésében. A PSI és PSII fotokémiai rendszerek hatékonysága magasabb a tetraploid vonalak leveleiben a kontroll diploid vonalakhoz képest mind szántőföldi, mind üvegházi körülmények között. A tetraploid füz genotípusokban megfigyelhető klorofill- és karotinoidtartalom is lényegesen magasabb volt, mint a diploid kontrollban, ami a fotoszintetikus hatékonyság funkcionális alapjának lényeges eleme.

\section{PUBLICATIONS (MTMT ID: 10031509)}

\section{Publications related to the Phd thesis:}

- Paul K, Pauk J, Deák Z, Sass L, Vass I. 2016. Contrasting response of biomass and grain yield to severe drought in Cappelle Desprez and Plainsman V wheat cultivars. PeerJ. 4:e1708; DOI 10.7717/peerj.1708. IF: 2.1

- Dudits D, Török K, Cseri A, Paul K, Nagy AV, Nagy B, Sass L, Ferenc G, Vankova R, Dobrev P, Vass I and Ayaydin F. 2016. Response of organ structure and physiology to autotetraploidy in early development of energy willow Salix viminalis L. Plant Physiology. Vol. 170, pp. 1504-1523.

\section{IF: 6.84}

\section{Other peer-reviewed publications:}

- Szalonek M, Sierpien B, Rymaszewski W, Gieczewska K, Garstka M, Lichocka M, Sass L, Paul K, Vass I, Vankova R, Dobrev P, Szcsesny P, Marczewski W, Krusiewicz D, Strzelczyk-Zyta D, Hennig J, KonopkaPostupolska D. 2015. Potato annexin STANN1 promotes drought tolerance and mitigates light stress in Transgenic Solanum tuberosum L. plants PLOS ONE 10(7): e0132683. doi:10.1371/journal.pone.0132683. IF: $\mathbf{3 . 2 3}$ 
- Vass IZ, Deák Z, Paul K, Kovács S, Vass I. 2015. Interaction of nanoparticles with biological systems. Acta Biol Szeged Volume 59 (Suppl.2): 225-245.

- Paul K, Deák Z, Csösz M, Purnhauser L and Vass I. 2011. Characterization and Early detection of Tan Spot Disease in Wheat in vivo with Chlorophyll Fluorescence Imaging. Acta Biologica Szegediensis; Volume 55(1): 87-90.

\section{Manuscripts under preparation}

- Paul K, Vass I and Solti A. 2016. Ecotype-level differences in the electron flow under desiccation and rehydration of the resurrection plant Haberlea rhodopensis. (manuscript submitted)

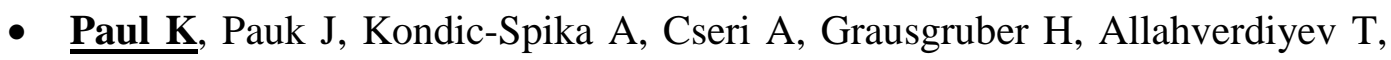
Deák Z, Sass L and Vass I. 2016. Synergistic effects of salt and drought stress in wheat studied by high throughput phenotyping and photosynthetic measurements. (manuscript under preparation)

- $\quad$ Paul K, Großkinsky D, Vass I and Roitsch T. 2016. Silver nanoparticles mitigates the Arabidopsis thaliana- Pseudomonas syringae infection. (manuscript under preparation)

- Keller B, Muller O, Matsubara S, Kolber Z, Paul K, Pieruschka R, Vass I, Rascher U. Electron transport time constants derived by light induced fluorescence transient (LIFT) method were validated and revealed cold response in the dark before photo inhibition took place. (manuscript under preparation)

- Digruber T, Sass L, Cseri A, Paul K, Nagy AV, Remenyik J, Molnár I, Vass I, Toldi O, Gyuricza C and Dudits D. 2016. Stimulation of biomass productivity 
of short rotation energy willow by pre-plantation treatment of stem cuttings with triacontanol or seeweed extract. (manuscript under preparation)

- Pesti R, Molnár J, Paul K, Vass I, Tusnády GE, Zoltán H and Várallyay E. Investigation of gene expression changes in virus infected tobacco and tomato plants. (manuscript under preparation)

\section{Conference Abstracts}

\section{Oral presentations}

- Paul K, Vass I and Solti A. Photosynthetic electron transport responses in detached leaves of two ecotypes of the resurrection plant Haberlea rhodopensis grown under natural habitat. Plant Biology Europe FESPB/EPSO 2016 Congress, 26 - 30th June 2016, Prague, Czech Republic. (T26. Plant Photochemistry session, ID:76)

- Paul K, Pauk J, Deák Z, Sass L, Vass I - Non-invasive plant phenotyping using photosynthetic tools to characterise 'biomass and grainyield' under water stress in wheat, COST FA 1306, I ${ }^{\text {st }}$ General meeting, June 22-24, 2015, IPK Gatersleben, Germany, pp.40.

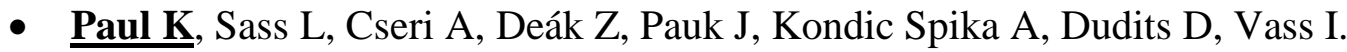
Plant phenotyping as a tool in optimizing crop productivity. Plant Biology Europe FESPB/EPSO 2014 Congress, 22nd - 26th June 2014, Dublin, Ireland, pp.94. (O103)

- $\underline{\text { Kenny Paul }}^{*}$ - Application of various imaging techniques in plant stress diagnostics. Szegedi Biológus Doktorandusz Konferencia, 19- 20 May, 2014, Szeged, Hungary. 
- $\quad$ Paul K, Deák Z, Sass L and Vass I. Application of non-invasive phenotyping approaches to characterize responses of wheat plants to water stress. Phenodays Conference, October $16^{\text {th }}$ to $18^{\text {th }}$ 2013, Kasteel Vaalsbroek, Netherlands, pp.30.

- Kenny Paul $^{*}$ - Testing leaf infections of wheat by digital photography and chlorophyll fluorescence imaging. Workshop on complex plant stress diagnostics "Improvement of cereals for conventional production and biofarming" Biocereal HUSRB/1002/214/045/02, 25 ${ }^{\text {th }}$ September 2013, Biological Research Centre, Szeged, Hungary.

- Kenny Paul $^{*}$ - Practical lecture and demonstrations on (i) Measurement of photosynthetic electron transport by Dual PAM (PSII + PSI) and (ii) Measurement of photosynthetic parameters by portable Chl fluorometers and Chl fluorescence imaging. June $30^{\text {th }}-J u l y 7^{\text {th }} 2013$, EPPN Summer School on Plant Phenotyping, Szeged, Hungary.

- Paul Kenny $^{*}$ - Application of imaging techniques for characterization and early detection of fungal infections in wheat leaves. $2^{\text {nd }}$ ITC Alumni Conference on "Multidisciplinary Approaches to Biological Problems", 1-3 ${ }^{\text {rd }}$ September 2011, Biological Research Centre- HAS, Szeged, Hungary, pp.37.

\section{Poster presentations}

- $\underline{\text { Paul K}}$, Vass I and Solti A. Electron flow responses in the ecotype level differences under desiccation and rehydration of the resurrection plant Haberlea rhodopensis. $2^{\text {nd }}$ general COST MEETING. $18^{\text {th }}-20^{\text {th }}$ of April 2016. Copenhagen, Denmark. 
- Pesti R, Paul K, Vass I, Zoltán H and Várallyay É. A vírusfertőzés tüneteinek kialakulásában szerepet játszó génexpressziós változások vizsgálata. a 62. Növényvédelmi Tudományos Napok 2016, február 16. A Magyar Növényvédelmi Társaság 8. közgyülésére, Széchenyi István tér 9, 1051 Budapest, pp.25.

- Vass I, Paul K, Pauk J, Kondic-Spika A, Grausgruber H, Allahverdiyev T, Deák Z, Sass L (2015) Synergistic effects of salt and drought stress on the growth and photosynthetic parameters of wheat. COST FA $1306, I^{\text {st }}$ general meeting, June 22-24, 2015, IPK Gatersleben, Germany. pp.52.

- Paul K, Deák Z, Sass L and Vass I. Non invasive plant phenotyping by using photosynthetic tools. $3^{\text {rd }}$ International Plant Phenotyping Symposium 17- 19 February 2014, Chennai, India, pp.40. (S 01)

- Digruber T, Sass L, Paul K, Molnár I, Vass I, Gyuricza C, Dudits D. Development of stimulation technologies to increase the biomass production of energy willow plants (Salix sp.). A Magyar Növénybiológiai Társaság XI. Kongresszusa 2014. Augusztus 27 - Augusztus 29. Szeged, MTA Szegedi Biológiai Kutatóközpont, pp.10.

- Paul K, Deák Z, Csösz M, Purnhauser L and Vass I. Application of chlorophyll fluorescence imaging for early plant disease diagnosis. 29 July to 3 August 2012, FESPB/EPSO Plant Biology Congress 2012, Freiburg, Germany. (P520)

- Kenny P, Deák Z, Csösz M, Purnhauser L and Vass I. Characterization and Early detection of Tan Spot Disease in Wheat in vivo with Chlorophyll Fluorescence Imaging. A Magyar Növénybiológiai Társaság X. Kongresszusa, $31^{\text {st }}$ August- $2^{\text {nd }}$ September 2011, Szeged, Hungary, pp.10. (S3- P04) 